College of William \& Mary Law School William \& Mary Law School Scholarship Repository

1968

\title{
The Demise of the Right-Privilege Distinction in Constitutional Law
}

William W. Van Alstyne

William \& Mary Law School

\section{Repository Citation}

Van Alstyne, William W., "The Demise of the Right-Privilege Distinction in Constitutional Law" (1968). Faculty Publications. 786.

https://scholarship.law.wm.edu/facpubs/786

Copyright c 1968 by the authors. This article is brought to you by the William \& Mary Law School Scholarship Repository. https://scholarship.law.wm.edu/facpubs 


\title{
THE DEMISE OF THE RIGHT-PRIVILEGE DISTINCTION IN CONSTITUTIONAL LAW
}

\author{
William W. Van Alstyne*
}

The right-privilege distinction, as it appeared in an early statement by Justice Holmes, has long hampered individuals reithin the public sector in protecting themselves against arbitrary governmental action. In this article Professor Van Alstyne reviews the uses and misuses to rehich the "privilege" concept has been put and then examines those doctrines whose flanking attacks have gradually eroded its efficacy. But none of these doctrines comes to grips with Holmes' basic idea of a "privilege" to which substantive due process is inapplicable. Applying Holmes' onen jurisprudence, the author argues that the concept of "privilege" is today no longer viable, and that the size and power of the governmental role in the public sector requires substantive due process control of the state in all its capacities.

$\mathrm{I}^{\mathrm{N}}$ $\mathrm{N}$ I892, Justice Holmes, speaking for the Massachusetts Supreme Judicial Court in McAuliffe v. Mayor of New Bedford, trenchantly dispatched the petition of a policeman who had been fired for violating a regulation which restricted his political activities: ${ }^{1}$

The petitioner may have a constitutional right to talk politics, but he has no constitutional right to be a policeman.

With customary bluntness Holmes went on to observe: ${ }^{2}$

There are few employments for hire in which the servant does not agree to suspend his constitutional right of free speech, as well as of idleness, by the implied terms of his contract. The servant cannot complain, as he takes the employment on the terms which are offered him.

A scant three years later, Justice Holmes had occasion to confirm this conception of the scope of constitutional protection in upholding the conviction of a preacher who had violated a municipal ordinance in presenting a public address on the Boston Common without securing a permit from the mayor. Noting that the Boston Common was governmentally owned, and dis-

* Professor of Law, Duke Law School. A.B., University of Southern California, I955; LL.B., Stanford, I958.

${ }^{1}$ I55 Mass. 216, 220, 29 N.E. 5I7, 5I7 (I892).

2 Id. at 220,29 N.E. at $5 \mathrm{I} 7-\mathrm{I} 8$. 
regarding the fact that the ordinance was utterly lacking in standards to control the mayor's discretion, Holmes added: ${ }^{\mathbf{3}}$

For the Legislature absolutely or conditionally to forbid public speaking in a highway or public park is no more an infringement of the rights of a member of the public than for the owner of a private house to forbid it in his house. When no proprietary right interferes, the Legislature may end the right of the public to enter upon the public place by putting an end to the dedication to public uses. So it may take the lesser step of limiting the public use to certain purposes.

Thus, it was as though Justice Holmes merely restated his earlier epigram: the defendant may have a constitutional right to talk religion, but he has no constitutional right to use the Boston Common.

This tough-minded distinction between constitutionally protected rights of private citizens and unprotected governmental privileges has been applied to defeat a great variety of claims associated with government employment or other forms of largess. In upholding the summary dismissal of a federal civil servant from a nonsensitive position on grounds of suspected disloyalty, for instance, a federal court of appeals has said: ${ }^{4}$ "The First Amendment guarantees free speech and assembly, but it does not guarantee Government employ." Similarly, the Tennessee Supreme Court abruptly rejected fourteenth amendment claims by a public school teacher punished for violating a statutory ban on the teaching of "any theory that denies the story of the divine creation": ${ }^{5}$

[Petitioner] had no right or privilege to serve the State except

\footnotetext{
${ }^{3}$ Commonwealth v. Davis, I62 Mass. 5Io, 5II, 39 N.E. II3, xI3 (I895), aff'd, I67 U.S. 43 (r897). But see Cox v. Louisiana, 379 U.S. 536 (x965); Hague v. CIO, 307 U.S. 496 (1939).

${ }^{4}$ Bailey v. Richardson, I82 F.2d 46, 59 (D.C. Cir. 1950), aff'd by an equally divided Court, 34r U.S. 9r8 (I95r). Compare Cafeteria Workers v. McElroy, 367 U.S. 886 (I96I) (summary dismissal of civilian cook on military installation upheld), with Greene v. McElroy, 360 U.S. 474, 496-97, 506-08 (1959) (revocation of security clearance of civilian aeronautical engineer without safeguards of confrontation and cross-examination held invalid in absence of explicit presidential or congressional authorization for agency procedures), and Willner v. Committee on Character, 373 U.S. 96 ( 1963 ) (state cannot deny admission to bar without meeting requirements of procedural due process). See also United Pub. Workers v. Mitchell, 330 U.S. 75 (1947) (Hatch Act upheld; extent of constitutional guarantees must be balanced against need for efficient civil service).

${ }^{5}$ Scopes v. State, I54 Tenn. I05, I09-IO, III-12, 289 S.W. 363, 364-65 (1927). But see Whitehill v. Elkins, 389 U.S. 54 ( 1967 ) (loyalty oath for state university void for overbreadth), and cases cited therein.
} 
upon such terms as the State prescribed. . . . In dealing with its own employees engaged upon its own work, the State is not hampered by the limitations of .... the Fourteenth Amendment to the Constitution of the United States.

And more recently, in I954, the Supreme Court upheld the suspension of a physician's license on equally tenuous grounds. The physician had been convicted of contempt of Congress for declining to produce certain papers for a committee of the House of Representatives. His license was suspended on the basis of this criminal conviction, even without a showing that his actions related to his competence or professional integrity as a physician: ${ }^{\circ}$

The practice of medicine in New York is lawfully prohibited by the State except upon the conditions it imposes. Such practice is a privilege granted by the State under its substantially plenary power to fix the terms of admission.

If this view were uniformly applied, the devastating effect it would have on any constitutional claims within the public sector can be readily perceived. ${ }^{7}$ A public housing tenant summarily evicted without a hearing or any stated reason should have no basis for complaint: surely one no more has a right to public housing than to public employment; in either case he simply takes the benefit on the terms offered him. ${ }^{8}$ An impoverished couple actually domiciled in a state should still have no complaint against a one-year residence requirement for welfare recipients: one may have a right to equal protection, but he has no right to public welfare. ${ }^{9}$ And certainly public university students sum-

\footnotetext{
${ }^{B}$ Barsky v. Board of Regents, $34 \nmid$ U.S. 442, 45 I (I954).

${ }^{7}$ Shepardizing $M c A$ uliffe yielded more than 70 cases, $77 \%$ of which resolved the decision against the constitutional claim being asserted. See, e.g., Hirschman v. Los Angeles County, 23 I P.2d I40 (Cal. Dist. Ct. App. I95I), aff'd, 39 Cal. 2d 698, 249 P.2d 287 ( 1952 ) (county employees dismissed for refusal to sign loyalty oath); Hornstein v. Illinois Liquor Control Comm'n, 4I2 Ill. 365, 106 N.E.2d 354 (I952) (summary revocation of liquor license without prior notice or hearing); Wilkie v. O'Connor, 26I App. Div. 373, 25 N.Y.S.2d 617 (I94I) (welfare pension cut off after recipient's insistence on "right to sleep under an old barn, in a nest of rags"); CIO v. City of Dallas, I98 S.W.2d I43 (Tex. Ct. Civ. App. I946) (injunction against no-union rule for city employees denied); Starkey v. Board of Educ., I4 Utah 2d 227, 38I P.2d 7 I8 (I963) (married high school student barred from extracurricular activities).

${ }^{8}$ See Housing Authority v. Thorpe, 267 N.C. 43I, 148 S.E.2d 290 (per curiam), vacated per curiam, 386 U.S. 670 ( 1967 ).

${ }^{\circ}$ But see Harrell v. Tobriner, 279 F. Supp. 22 (D.D.C. I967); Thompson v. Shapiro, 270 F. Supp. 33I (D. Conn. I967), prob. juris. noted, 36 U.S.L.W. 3286
} 
marily expelled or suspended should have no constitutional grounds for reinstatement, for it must be equally clear that while petitioners may have a right to procedural due process, they have no right to be educated at public expense. ${ }^{10}$

Fortunately, however, the right-privilege distinction has not in fact removed all restraints from the government in the public sector. Although in some cases it has been misapplied to facts which did not come within its rationale at all, in others it has not been applied even though the facts did fit its rationale. Increasingly, when the petitioner's primary interest in the public sector could not be characterized as a "right" entitled to protection on grounds of substantive due process, courts have nonetheless found some other implicated right to sustain the claim. Alternatively, they have granted relief through recourse to constitutional provisions which operate irrespective of whether what is involved is deemed a privilege, rather than a right. While the concept of "privilege" underlying Holmes' epigram remains nominally intact, its implications for positive law have been gradually eroded. After considering those situations where the rightprivilege distinction has been misapplied, I propose to review those means which the Supreme Court has utilized to avoid the harsh consequences of the distinction, and then to reexamine the essential soundness of the distinction itself.

\section{AN EPIgram Overdone}

The notion that "the petitioner has no right to be a policeman" is a specific application of the larger view that no one has a constitutional right to government largess. ${ }^{11}$ This view distinguishes the limited power of the state "reasonably" to regulate activities conducted by private means without substantial assistance by government from the unlimited power of the state to regulate advantages supplied by government without obligation. The conception of unprotected state-bestowed privileges was not

(U.S. Jan. I5, I968) (No. 813); Green v. Department of Pub. Welfare, 270 F. Supp. I73 (D. Del. I967).

${ }^{10}$ Compare Hamilton v. Regents of Univ. of Calif., 293 U.S. 245, 262 (1934) (requirement to take military science course as condition of enrollment upheld), with Dixon v. Alabama State Bd. of Educ., 294 F.2d 150 (5th Cir.), cert. denied, 368 U.S. 930 ( $\mathrm{x} 96 \mathrm{x}$ ) (procedural due process required for expulsion of students in good standing at tax-supported college).

11 The phrase "government largess" is used to describe the origin of a status dependent upon government expenditures solely in deference to the conventional view that such expenditures are initiated without constitutional obligation. 
originally designed to curtail claims of substantive due process in the private sector. ${ }^{12}$ An individual could still directly assail a state statute affecting his private employment on the ground that it unreasonably regulated his right to work or right to contract, without having to show it also indirectly curtailed some separately named constitutional interest such as his freedom of speech. As the Court suggested in Meyer v. Nebraska, in invalidating a state statute forbidding teachers from providing instruction in German even in private schools: ${ }^{13}$

The established doctrine is that this liberty [guaranteed by the due process clause] may not be interfered with, under the guise of protecting the public interest, by legislative action which is arbitrary or without reasonable relation to some purpose within the competency of the State to effect. Determination by the legislature of what constitutes proper exercise of police power is not final or conclusive but is subject to supervision by the courts.

If the basic distinction implied by Holmes in McAuliffe is kept in mind, cases of the same general period, such as Hamilton v. Regents of the University of California ${ }^{14}$ are not inconsistent with Meyer. In Hamilton, as in McAuliffe, petitioners were complaining of regulations attached to something they sought from the state rather than something they had secured in the private sector without public assistance. Students excluded from the state university for failing to take military training were therefore unable to argue on the basis of substantive due process that they had a "right to acquire useful instruction," since the instruction they sought was dependent on government largess. ${ }^{15}$ How-

\footnotetext{
${ }^{12}$ The sources of substantive due process antecedent to the Constitution are well described in E. Corwin, The "Higmer Law" Background of AMarrican Constitutional Law (I955). For subsequent developments see J. JaMes, THE FraMING OF THE FOURTEENTH AMIENDMENT (I956); J. TENBROEK, EQUAL UNDER LAW (1965); Graham, Procedure to Substance-Extra-Judicial Rise of Due Process, 1830-r860, 40 CaLIF. L. REv. 483 (I952); Howe, The Meaning of "Due Process of Law" Prior to the Adoption of the Fourteenth Amendment, I8 CAIIF. L. REv. 583 (1930).

${ }_{13} 262$ U.S. $390,399-400$ (I923); see Pierce v. Society of Sisters, 268 U.S. 5 IO (I925) (invalidating compulsory public school attendance); Truax v. Raich, 239 U.S. 33 (1915) (invalidating state limitation on employment of aliens). See also Loving v. Virginia, 388 U.S. I, I2 (I967); Griswold v. Connecticut, 38 I U.S. 479 (I965); Aptheker v. Secretary of State, 378 U.S. 500 (rg64).

14293 U.S. 245 (I934).

15 The only argument available to petitioners in Hamilton was based on the doctrine of unconstitutional conditions, discussed at pp. I445-49 infra. In this regard they argued (unsuccessfully) that the ROTC requirement operated as an unconstitutional condition upon their freedom of religion to the extent that they had a conscientious objection to military training.
} 
ever, other cases relying upon the McAuliffe view blurred the distinction upon which it was based. In Barsky v. Board of Regents, ${ }^{16}$ for instance, the physician whose license was suspended following his conviction of contempt of Congress was not merely dropped from a public job. Not even on the public payroll to begin with, he was forbidden under pain of criminal prosecution to practice medicine privately. What had happened was that, over a period of time, the Court had recognized that even the personal liberty to contract in the private sector, to work in the private sector, or to own property was subject to a high degree of reasonable governmental regulation in the public interest against the claim that such "rights" were absolutely protected by the fourteenth amendment. This recognition emerged in an irregular line of thoughtful cases beginning no later than Munn v. Illinois ${ }^{17}$ and tracing through Holden v. Hardy ${ }^{18}$ and Muller v. Oregon. ${ }^{19}$ It was made firm through Nebbia v. New York ${ }^{20}$ and has been consistently followed to the present time. ${ }^{21}$ In recognizing that the "right" to own property or the "right" to work in the private sector is necessarily subject to public regulation compatible with some minimum standard of substantive due process, however, the Court had never asserted that such an interest was wholly outside the protection of the due process clause. But cases such as Barsky tacitly moved toward the proposition that because the private sector is subject to considerable public regulation, even the exercise of a prerogative in the private sector is merely a privilege, and can stand on no better footing than other kinds of privileges - such as those in the public sector. ${ }^{22}$ Thus the Court moved by negligent degrees in a few aberrant cases to the following neologism: the petitioner may have a right to talk politics, but he has no right to be a doctor-

${ }^{16} 347$ U.S. 442 (1954).

1794 U.S. II3 (I877).

${ }^{18}$ I6g U.S. 366 (I8g8).

19208 U.S. 4 I2 (Ig08).

${ }^{20} 29$ I U.S. 502 (I934).

${ }^{21}$ See, e.g., Ferguson v. Skrupa, 372 U.S. 726 (1963). See generally Jacobson, Federalism and Property Rights, 15 N.Y.U.L.Q. REv. 319 (1938); McCloskey, Economic Due Process and the Supreme Court: An Exhumation and Reburial, I962 Sup. CT. Rev. 34; Rodes, Due Process and Social Legislation in the Supreme Court-A Post Mortem, 33 Notre Dame Law. 5 (I957).

${ }^{22}$ See, e.g., Hornstein v. Illinois Liquor Control Comm'n, 412 Ill. 365, 106 N.E.2d 354 (I952) (revocation of liquor license); Morley v. Police Comm'r, 26r Mass. 269, 276-77, I59 N.E. 4r, 43 (I927), cert. denied, 276 U.S. 625 (1928) (suspension or revocation of hackney license); cf. W. GeLlHors, INDIVIDUAL FrEedOMI AND GoVERNMENTAI RESTRAINTS IO5-5I (I956). 
even a private one. The excerpt from Barsky is so instructive on this point as to bear repeating: ${ }^{23}$

The practice of medicine in New York is lawfully prohibited by the State except upon the conditions it imposes. Such practice is a privilege granted by the State under its substantially plenary power to fix the terms of admission.

\section{ERODING THE EPIGRAMI}

Nearly a half dozen means are currently available to circumvent the harsh consequences of the right-privilege distinction as applied to private interests in the public sector. Each peacefully coexists with the Holmes epigram, for none involves any direct repudiation of the right-privilege distinction as a limitation on claims of substantive due process in the public sector. But the extent to which these devices are available depends upon the circumstances, and all but one have substantial practical limitations.

\section{A. The Doctrine of Unconstitutional Conditions}

The doctrine of unconstitutional conditions ${ }^{24}$ takes for granted that "the petitioner has no right to be a policeman," but it emphasizes the right he is conceded to possess by reason of an explicit provision in the first amendment, his "right to talk politics." As stated by Mr. Justice Sutherland in I926: ${ }^{25}$

It would be a palpable incongruity to strike down an act of state legislation which, by words of express divestment, seeks to strip the citizen of rights guaranteed by the federal Constitution, but to uphold an act by which the same result is accomplished under the guise of a surrender of a right in exchange for a valuable privilege which the state threatens otherwise to withhold. . . . If the state may compel the surrender of one constitutional right as a condition of its favor, it may, in like manner, compel a surrender of all. It is inconceivable that guarantees embedded in the Constitution of the United States may thus be manipulated out of existence.

Essentially, this doctrine declares that whatever an express con-

${ }^{23} 347$ U.S. at 45 r.

${ }^{24}$ The doctrine has been widely discussed. See, e.g., Hale, Unconstitutional Conditions and Constitutional Rights, 35 CoLUM. L. Rev. $32 \mathrm{~T}$ (I935); O'Neil, Unconstitutional Conditions: Welfare Benefits with Strings Attached, 54 CarTr. L. Rev. 443, 463-66 (I966); Note, Unconstitutional Conditions, 73 HARv. L. REV. 1595,1596 (I960).

${ }^{25}$ Frost \& Frost Trucking Co. v. Railroad Comm'n, 27 I U.S. 583, 593-94 (1926). 
stitutional provision forbids government to do directly it equally forbids government to do indirectly. As a consequence, it seems to follow that the first amendment forbids the government to condition its largess upon the willingness of the petitioner to surrender a right which he would otherwise be entitled to exercise as a private citizen. The net effect is to enable an individual to challenge certain conditions imposed upon his public employment without disturbing the presupposition that he has no "right" to that employment.

The unconstitutional conditions doctrine has been applied, for example, to forbid a state to discontinue unemployment benefits to a person refusing Saturday employment for religious reasons. ${ }^{20}$ And it has been employed to protect the status of state college students from summary termination, against the argument that the privilege of attendance had been conditioned upon their acceptance of a rule permitting summary dismissal. ${ }^{27}$ The doctrine would appear to apply equally well to every other case where the enjoyment of a government-connected interest is conditioned upon a rule requiring that one abstain from the exercise of some right protected by an express clause in the Constitution. Literal application of the doctrine might mean, for instance, that a welfare recipient need not consent (and cannot be held by his economically coerced consent) to a warrantless search of his lodgings absent circumstances otherwise justifying an equivalent administrative search of private premises occupied by one not on welfare. ${ }^{28}$ It would also suggest that a policeman can no more be made to waive his privilege against self-incrimination than

${ }^{26}$ Sherbert v. Verner, 374 U.S. 398,404 (I963): "It is too late in the day to doubt that the liberties of religion and expression may be infringed by the denial of or placing of conditions upon a benefit or privilege."

27 Dixon v. Alabama State Bd. of Educ., 294 F.2d I50, 156 (5th Cir.), cert. denied, 368 U.S. 930 ( $\mathrm{I} 96 \mathrm{r}$ ) ("the State cannot condition the granting of even a privilege upon the renunciation of the constitutional right to procedural due process"). For other applications see, e.g., Speiser v. Randall, 357 U.S. 513, 51920 (1958) (special veterans' exemption from state tax cannot be conditioned on a loyalty oath); Standard Airlines, Inc. v. CAB, I77 F.2d I8, 20 (D.C. Cir. 1949) ( $\mathrm{CAB}$ cannot condition a flying permit on consent to discretionary summary revocation); Lawson v. Housing Authority, 270 Wis. 269, 275, 70 N.W.2d 605, 608-09, cert. denied, 350 U.S. 882 (I955) (tenant in public housing may challenge regulation requiring certification of nonmembership in certain "subversive" organizations as conditions of continued occupancy).

${ }^{28}$ Compare Parrish v. Civil Service Comm'n, 425 P.2d 223, 57 Cal. Rptr. 623 (Sup. Ct. I967) (welfare payments cannot be conditioned on consent to submit to warrantless searches), with Camara v. Municipal Ct., 387 U.S. 523 (I967) (housing code regulation which provided for warrantless administrative searches struck down). 
can a private attorney. ${ }^{29}$ It would further imply that the decision in United Public Workers v. Mitchell, ${ }^{30}$ upholding the constitutionality of the Hatch Act, was incorrect, since the political activity pursued by the civil servant in that case was doubtless protected by the first amendment from direct regulation as applied to private citizens. ${ }^{31}$ As an "exception" to the right-privilege distinction, the doctrine seems to be a very broad one which is subject only to one major limitation: the petitioner must demonstrate that the condition of which he complains is unreasonable in the special sense that it prohibits or abridges the exercise of a right protected by an explicit provision in the Constitution. ${ }^{32}$ It provides no protection against a regulation which is simply unreasonable or even outrageous in that it has no reasonable connection with any legitimate public purpose, for in that case only the petitioner's public status is menaced - something to which he presumably has no "right" to begin with. ${ }^{33}$

The doctrine of unconstitutional conditions is highly attractive for two quite practical reasons. First, it preserves the appearance of judicial objectivity. A court need not "weigh" or "balance"; it need simply apply the literal mandate of a given constitutional provision flatly to forbid government from conditioning its largess on any waiver of such a provision regardless of the circumstances. A court may thus avoid any unseemly appearance of acting as a superlegislature. Second, the doctrine greatly expedites decision making and provides clear guidelines in cases which might otherwise be especially difficult to resolve. Instead of canvassing a host of variables in a quasi-legislative fashion on the strength of a

\footnotetext{
${ }^{28}$ Compare Garrity v. New Jersey, 385 U.S. 493 (I967), with Spevack v. Klein, 385 U.S. 5 II (I967).

${ }^{30} 330$ U.S. 75 (1947).

${ }^{31}$ But see pp. 1448-49 infra.

32 There are all sorts of difficulties in trying to make sense of such a distinction, for reasonable persons may surely disagree as to which provisions are "explicit." But see United States v. Lovett, 328 U.S. 303, 32I (I946) (Frankfurter, $\mathrm{J}$., concurring). One might also wonder why the doctrine of unconstitutional conditions should be confined to rights which are more or less explicitly described, and why it does not extend equally to rights worked out by implication from more general provisions such as the ninth amendment and the (substantive) due process clauses of the fifth and fourteenth amendments. The fact remains, however, that the doctrine has seldom been applied other than to explicit rights, notably freedom of speech.

${ }^{33}$ See, e.g., Carraway v. Jefferson Parish School Bd., 25I F. Supp. 462, 465 (E.D. La. Ig66). For a better and more qualified expression of this view, see Linde, Constitutional Rights in the Public Sector: Justice Douglas on Liberty in the Welfare State, 40 WASH. L. REv. 10, 76 (Ig65).
} 
barely adequate record, a court may seem to have but a single straightforward question to resolve: did the regulation in question condition the petitioner's privilege upon the waiver of a named constitutional right? ${ }^{34}$

Mr. Justice Holmes, however, consistently with his earlier holding in McAuliffe, never fully accepted the unconstitutional conditions doctrine and was probably correct in believing that in its absolute form it evaded the more difficult question raised by justifiable state regulations. ${ }^{35}$ The basic flaw in the doctrine is its assumption that the same evil results from attaching certain conditions to government-connected activity as from imposing such conditions on persons not connected with government. In many cases this may be true, but the connection with the government may in certain circumstances make otherwise unreasonable conditions quite reasonable. In Holmes' view, even rights protected by an express provision of the Constitution were relative and might be made to yield to certain necessities. To forbid the false shouting of "Fire!" in the crowded theater was not to reach the "same result" as to forbid shouting in one's bedroom..$^{36}$ To limit a policeman's privilege against self-incrimination in connection with questions immediately related to his job as a policeman, and solely in order to determine whether there is just cause to discharge him or at least to make further inquiry, would not be the "same thing" as to require answers of citizens in police custody for the purpose of aiding their criminal prosecution. The judicial result cannot be made to turn upon such a pretended "sameness." Thus to hold that the privilege against self-incrimination applies to public employees should not prevent the government, under appropriate circumstances, from making inquiry of an employee respecting his job. ${ }^{37}$ And, under the facts of McAuliffe, the existence of a right to talk politics ought not

\footnotetext{
34 Compare Gideon v. Wainwright, 372 U.S. 335 (1963), and Miranda v. Arizona, 384 U.S. 436 (1966), with Betts v. Brady, 316 U.S. 455 (r942), and Davis v. North Carolina, 384 U.S. 737, 739-40 (xg66). But see note 32 stipra.

${ }^{35}$ See, e.g., Frost \& Frost Trucking Co. v. Railroad Comm'n, $27 \mathrm{I}$ U.S. 583, 600-02 (x926) (Holmes, J., dissenting).

${ }^{38}$ See Schenck v. United States, 249 U.S. 47, 52 (Igrg).

${ }^{37}$ Cf. American Bank \& Trust Co. v. Federal Reserve Bank, 256 U.S. 350,358 (x92I) (Holmes, J.):

[T] he word "right" is one of the most deceptive of pitfalls; it is so casy to slip from a qualified meaning in the premise to an unqualified one in the conclusion. Most rights are qualified. A man has at least as absolute a right to give his own money as he has to demand money from a party that has made no promise to him; yet if he gives it to induce another to steal or murder the purpose of the act makes it a crime.
} 
necessarily to mean that it can be exercised in violation of a departmental regulation while one is in government service, at least if the character of the governmental position necessitates the restriction of this right in the interest of a compelling public good. ${ }^{38}$ Yet the unconstitutional conditions doctrine, while attaching no constitutional significance to the status in the public sector, may lack the flexibility adequately to treat such problems.

\section{B. "Indirect Effects" and Constitutional Rights}

The doctrine of unconstitutional conditions has usually been applied only to regulations which directly forbid the enjoyment of an explicit constitutional right. The doctrine has been of little assistance in those situations, however, where the regulation of status in the public sector has had only an indirect effect on such a right, without directly and wholly forbidding its exercise. The Supreme Court has nonetheless occasionally protected the petitioner's status under such circumstances by emphasizing the "unconstitutional effect" of the regulation, although still leaving undisturbed the conventional view that one has no constitutional right per se to status in the public sector. The character of constitutional review is more complex in such cases than in those typically believed to involve unconstitutional conditions, however; and it correspondingly begs fewer questions. The Court attempts to balance competing public and private concerns to determine whether the regulation as applied has a suffcient connection with important enough state interests to outweigh the incidental effect on the constitutional rights of the affected class.

An excellent illustration of such an approach is provided by Shelton v. Tucker. ${ }^{39}$ A closely divided Court invalidated an Arkansas statute requiring every public school teacher annually to file an affidavit listing every organization to which he belonged or to which he had regularly contributed within the preceding five years. The statute itself did not penalize membership in any group..$^{40}$ Thus, the claim did not lend itself to quick judicial

${ }^{38}$ But see United Pub. Workers v. Mitchell, 330 U.S. 75 (I947). In fact, Holmes seems to have gone even further than this and to have felt that the "reasonableness" of a regulation could be somewhat more liberally construed when a privilege rather than a right was involved. See Frost \& Frost Trucking Co. v. Railroad Comm'n, 27 I U.S. 583, 602 (I926) (Holmes, J., dissenting).

${ }^{39} 364$ U.S. 479 (Ig60).

${ }^{40}$ Nor did the statute provide that disclosure of membership would have to be furnished whether or not a given teacher felt that such a disclosure would tend 
dispatch through a mechanical holding that freedom of association is protected by the first amendment and that the doctrine of unconstitutional conditions forbids a state to condition its favor upon the surrender of a constitutional right. Had the Court wanted to apply the doctrine of unconstitutional conditions, it would first have had to hold that the first amendment broadly guarantees, in addition to the freedom to speak, an absolute right of nondisclosure respecting one's political views and associations. It might then have held that the Arkansas statute operated as an unconstitutional condition against that right. Such an expansive right is not readily apparent on the face of the amendment, however, and a formulation broad enough for the case at hand would have had serious implications in related areas. It might, for example, have raised serious doubts as to the validity of the present limitations on the prerogative of a witness before a congressional investigating committee to decline to answer any relevant and substantially non-incriminating questions. ${ }^{41}$ The doctrine of unconstitutional conditions, mechanically applied, might not furnish room to make distinctions as to the reasonableness of the demand for information under all the circumstances.

In Shelton $v$. Tucker, the Court eschewed the unconstitutional conditions doctrine and instead undertook a more difficult and painstaking inquiry. It guessed the probable effect of the statute in discouraging controversial political association, in light of the lack of a tenure system to provide job security. It acknowledged the state's legitimate but uncompelling interest in avoiding possible conflicts of interest and time-consuming commitments on the part of its employees. It also noted that less ominous means were open to the state to protect its interests than the compilation of unconfidential and indiscriminately inclusive membership lists. A majority of five finally concluded that the statute was invalid in view of its chilling effect on the exercise of the first amendment freedoms of association and speech. ${ }^{42}$

The form of analysis used by the Court in Shelton reflects a

to incriminate him. Thus no fifth amendment issue was presented. Compare Communist Party v. Subversive Activities Control Bd., 36y U.S. I (rg6r), with Albertson v. Subversive Activities Control Bd., 382 U.S. 7o (1965).

${ }^{41}$ The Court has typically eschewed a "right of silence" approach in this area in favor of a balancing of the indirect effects of the inquiry against the alleged need for and relevance of the information. See, e.g., Gibson v. Florida Legislative Investigation Comm., 372 U.S. 539 ( 1963 ), and cases cited therein.

${ }^{42}$ For a critical review of the case, see A. Bickex, The Least Dangerous BrancH 5I-55, 203-04 (I962). 
more fundamental difference between the unconstitutional conditions and indirect effects doctrines than can be accounted for by the mere presence or absence of a direct ban on the exercise of a constitutional right. Presumably the Court could have limited its inquiry to whether the Arkansas statute might indirectly produce the same result in its infringement of freedom of association as would a direct prohibition on membership in certain groups. It could thus have avoided the speculative weighing of offsetting private and public interests, for any such regulation which would have the effect of infringing first amendment guarantees could be struck down as an unconstitutional condition on public employment. But the weakness of the unconstitutional conditions doctrine was that in its very ease of application it failed to attach any significance to the legitimate public purposes which any regulation might serve. In contrast, Shelton v. Tucker quite carefully focuses on the competing interests involved. It would presumably have been decided differently if the state had been able to show (a) a stronger public interest, (b) a closer connection between the information requested and the protection of important public interests, or (c) the lack of any feasible alternative means adequately to guard against employee conflicts of interest. The result might have been different, that is, even though the degree of indirect effect on freedom of association would have remained constant. ${ }^{43}$ Thus, the indirect involvement of a specific constitutional interest does not, as under the mechanical application of the doctrine of unconstitutional conditions, necessarily or as readily guarantee the invalidity of the regulation.

However, even the indirect effects group of cases fails to impair the conventional view that status in the public sector does not itself present a constitutionally protected interest. The petitioners in Shelton were not able to claim that the Arkansas statute was a constitutionally unreasonable regulation of their employment; the condition on their public status again was vulnerable only because it was a constitutionally unreasonable regulation of their first amendment freedom of association.

\section{Procedural Due Process}

Although there are only a few cases in which a procedural argument is clearly featured, a person may sometimes success-

\footnotetext{
${ }^{43}$ Cf., e.g., Communist Party v. Subversive Activities Control Bd., 367 U.S. I, 88-I05 (x96I).
} 
fully rely on an independent right to procedural due process to avoid some of the harsh consequences of the right-privilege distinction. Again, however, this argument outwardly does not reject the major premise of that distinction. In the first instance, a requirement of a minimally fair hearing holds only that whenever the legislature has seen fit to limit the grounds for terminating or denying certain benefits, the administering agency must still observe certain minimum procedural standards to provide reasonable assurance that the petitioner did in fact offend one of the specified grounds; but the power of Congress or a state legislature to set substantive standards without constitutional restriction is not denied. Thus, the petitioner may have no right to talk politics while in the public service, but still he may not be discharged without an adequate hearing which may fairly determine whether in fact he had been talking politics. As Mr. Justice Jackson put it: ${ }^{44}$

The fact that one may not have a legal right to get or keep a government post does not mean that he can be adjudged ineligible illegally.

Accordingly, the constitutional right to procedural due process can be made to operate independently of whether the petitioner has a "right" to talk politics or a "right" to be a policeman. It comes in from the outside to build in the assurance provided by fair procedures that a decision is in fact supportable on whatever grounds the legislature or an agency itself has provided. The character of the hearing to which a person may be constitutionally entitled may depend upon the importance of what he stands to lose, of course, but his constitutional right to procedural due process entitles him to a quality of hearing at least minimally proportioned to the gravity of what he otherwise stands to lose through administrative fiat.

The need for procedural due process may also be derived from

\footnotetext{
${ }^{44}$ Joint Anti-Fascist Refugee Comm. v. McGrath, 34I U.S. I23, I85 (I96I) (concurring opinion); see Homer v. Richmond, 292 F.2d 719, 722 (D.C. Cir. Ig6r):

One may not have a constitutional right to go to Baghdad, but the Government may not prohibit one from going there unless by means consonant with [procedurall due process of law.

United States ex rel. Smith v. Baldi, I92 F.2d 540, 544 (3d Cir. I95I), aff'd, 344 U.S. 56I (1953):

[Appellant] is entitled to have procedural due process observed in the protection of these substantive rights even though substantive due process would not compel the rights to be given.

See also Greene v. McElroy, 360 U.S. 474 (1959).
} 
the concept of unconstitutional conditions. If the unconstitutional conditions doctrine is sound in holding that government may not terminate or withhold benefits according to standards it is constitutionally forbidden to impose upon private citizens, then it would seem to follow that a person whose status in the public sector is threatened by administrative action should have a right to a fair hearing to make certain that the administrative action is not in fact being taken for reasons which are constitutionally improper. Otherwise, the doctrine could be effectively undermined by wholly insulating unconstitutional administrative action from discovery and correction. The problem in Thorpe v. Housing Authority ${ }^{45}$ may illustrate this point. Mrs. Thorpe occupied a public housing unit under an agreement providing for unilateral termination by the Authority on fifteen days' notice without a hearing or the statement of any reason - a provision permitted by federal statute as of the time of her eviction. Suggestively soon before the day she was served with an eviction notice, she had been elected chairman of a tenants' association. From the face of the pleadings, it is fair to assume that her activity in this regard was wholly protected by the first amendment, and that a published standard providing for her automatic eviction for exercising her freedom of association would be set aside as an unconstitutional condition upon her first amendment rights. Manifestly, however, those rights can be effectively destroyed if the agency can oust her without any procedure suitable to guard against the likelihood that its decision is in fact based upon antagonism to her exercise of first amendment rights. Thus, it may be fair to say that the first amendment itself can impose a duty of procedural due process upon those otherwise bound by its provisions, and can establish a right to procedural due process for those whom its provisions are substantively intended to protect. On the other hand, as matters currently stand, constitutional claims to procedural due process in the public sector are not absolute, and even important private interests can still be taken away without an adequate hearing. It is as yet unclear whether the doctrine of unconstitutional conditions will import a right to procedural due process in all cases or only when the administrative decision rests prima facie on some basis violative of an explicit collateral right (such as freedom of speech); if the

\footnotetext{
${ }^{45} 386$ U.S. 670 ( 1967 ) (per curiam). In Thorpe itself a change in agency procedure, under which a hearing would be required, enabled the Court to avoid the constitutional issue.
} 
more limited view is adopted, the doctrine itself would be insuffcient to establish procedural safeguards against decisions which are wholly unreasonable but do not imperil such explicit rights.

Moreover, the additional benefits to be gained even from an absolute right to procedural due process are limited. Although the right to some form of process may be absolute, the extent to which particular safeguards are available nonetheless varies according to the circumstances. Where the consequence of error is relatively insubstantial, protection against the risk of error through the use of elaborate quasi-judicial procedures is subject to a constitutional trade-off with the need for administrative and fiscal economy. A student who stands in peril only of being on social probation may understandably be judged with greater informality than one in peril of outright expulsion, just as a job applicant need not receive the same type of circumspect hearing as a long-time employee whose employment alternatives have dwindled away and who is faced with the threat of discharge. In addition, where substantive statutory standards have been met - or where there are no such standards - and there is no recognized constitutional infringement, the right to procedural due process will not serve to expand substantive rights. Procedural due process alone would not, for example, protect Mrs. Thorpe from eviction for no reason at all where no reason is required under the governing statute. Yet despite these limitations, a right to procedural due process is desirable; a hearing can expose to public view arbitrary or inequitable grounds for a decision, thus facilitating a political remedy even where no legal remedy is available, and may serve to establish the channels for an individual to present his viewpoint to otherwise inaccessible administrators.

\section{Equal Protection}

The greatest circumvention of the distinction has been achieved via the equal protection clause. Under that clause, it seemingly makes no difference that the threatened interest is a privilege rather than a right. Even a privilege, benefit, opportunity, or public advantage may not be granted to some but withheld from others where the basis of classification and difference in treatment is arbitrary. As Mr. Justice Clark stated in Wieman v. Updegraff, in striking down a state loyalty oath read as containing no requirement of scienter: ${ }^{40}$

\footnotetext{
${ }^{46} 344$ U.S. I83, I92 (I952).
} 
We need not pause to consider whether an abstract right to public employment exists. It is sufficient to say that constitutional protection does extend to the public servant whose exclusion pursuant to a statute is patently arbitrary or discriminatory.

This reasoning in Wieman seems to summarize the following more elaborate equal protection argument. It may well be that no one has a right to secure or to maintain public employment. In determining whom to admit or whom to continue in public employment, however, government may not classify individuals as eligible or ineligible where the basis of classification is "arbitrary or discriminatory." A regulation which restricts the continuing eligibility of employees to the class willing to conform to an unreasonable rule of conduct ipso facto establishes an arbitrary classification. Such a regulation denies equal protection and is therefore unconstitutional. ${ }^{47}$

In the unconstitutional conditions and indirect effects cases, as we have observed, the petitioner has been obliged to show in what way the regulation adversely affects some interest readily recognized as falling within some fairly explicit provision of the Bill of Rights, such as his freedom of speech or religion, his right to privacy, or his privilege against self-incrimination. But since a legislative classification may be arbitrary on grounds other than that it adversely affects any of these particular interests, it is clear that the scope of equal protection is not limited to regulations infringing only one or more of these traditionally recognized rights. And since virtually every regulation of the public sector falls short of universality, the equal protection clause in this fashion may ultimately enable the petitioner constitutionally to challenge the reasonableness of the rule or condition affecting his status in the public sector, whether or not the rule is unreasonable only in the narrow sense that it menaces a "right" protected by an express provision in the Constitution. In this respect, a claim of equal protection is freed of the limitations which apply to the doctrine of unconstitutional conditions and to the indirect effects cases.

When viewed in this manner, an equal protection claim may, in fact, enable the petitioner effectively to raise virtually the

${ }^{47}$ Wieman can also perfectly well be analyzed as a case in which the decision was based upon an indirect effects or even an unconstitutional conditions approach. However, it seems more plausibly to be an equal protection case, especially since the Court's choice of words ("arbitrary," "discriminatory") tends to describe an invalid scheme of legislative classification. 
same arguments that he could have raised directly under a concept of substantive due process as applied to interests in the public sector. A systematic review of the equal protection and due process lines of cases would, I believe, readily establish that the constitutional tests of "arbitrary classification" are rapidly becoming indistinguishable from the constitutional tests of "unreasonable regulation" under the due process clause. Indeed, it is fair to say that the two clauses have almost completely merged. When a direct substantive due process claim is raised against a general regulation, the Court tends to assign a certain value to the private interest which is being pressed and then proceeds to require that the regulation be more or less rationally connected to an allowable public interest not equally capable of accomplishment by alternative means less detrimental to the private interest. When an equal protection claim is raised against a legislative classification, the Court also tends to assign a certain value to the private interest which is being pressed and then proceeds to require that the basis of the classification be more or less rationally connected to an allowable public interest not equally capable of accomplishment by alternative means less detrimental to the private interest. ${ }^{48}$ And the private interest may be, as in Wieman, primarily an interest in a public job, or, as in Brown v. Board of Education, ${ }^{40}$ an interest in a public education, or, as in Douglas v. California, ${ }^{60}$ an interest in an appeal from a felony conviction - none of which is a "right" protected under the due process clause..$^{51}$

The potentialities for overthrowing restrictions attached to government largess which courts may hold to be "unreasonable" through the use of the equal protection clause are only begin-

\footnotetext{
${ }^{48} \mathrm{I}$ do not in the least mean to imply that the Supreme Court is reckless or unconstrained in its manner of ascertaining and balancing the respective interests. Indeed, given the nature of the Constitution, I see no alternative to this kind of inquiry so long as judicial review is with us.

${ }^{49} 347$ U.S. 483 (I954).

${ }^{50} 372$ U.S. 353 ( 1963$)$.

51 But of. note 53 infra (interest in public education held protected by due process). It might be argued that a meaningful distinction still exists between claims of equal protection and claims of due process, in that the former can be disposed of any time government elects wholly to withdraw a particular privilege, while the rights upon which substantive due process is based cannot similarly be systematically destroyed. However, the likelihood of a state abandoning its system of public education or its appellate procedure, or withdrawing from the field of public employment is small. So long as the state continues to operate in the public sector, claims based on the equal protection clause should continue to avoid the rightprivilege problem.
} 
ning to achieve recognition. Yet an approach which treats arbitrary rules or actions in terms of their discriminatory effects is capable of greatly extending constitutional safeguards into the expanding public sector, as recent decisions striking down one-year residency requirements for welfare assistance demonstrate. ${ }^{52}$ This use of the equal protection clause, although it does not qualify the right-privilege distinction, does succeed in rendering it inconsequential..$^{53}$

\section{E. Bills of Attainder}

In the case of American Communications Association $v$. Douds, ${ }^{54}$ a majority of the Supreme Court upheld a provision of the Taft-Hartley Act ${ }^{55}$ which denied access to the National Labor Relations Board to any labor union whose officers declined to file noncommunist disclaimer affidavits. In that case, the Court rejected a claim that this provision constituted a bill of attainder in violation of article I, section 9 of the Constitution. $^{56}$ In 1965 , however, the Court in United States v. Brown ${ }^{57}$ adopted the argument in invalidating a successor provision of the statute; ${ }^{58}$ the disabling of a certain fixed group from serving as officers in a union constituted a sufficient "penalty" to be noticeable under the attainder clause. Although this is not the place to analyze Broven or the full requirements of a claim of attainder, it should be sufficient to note that this argument, in

52 E.g., Harrell v. Tobriner, 279 F. Supp. 22 (D.D.C. I967); Green v. Department of Pub. Welfare, 270 F. Supp. x73 (D. Del. I967).

${ }^{53}$ One theoretical limitation on the effectiveness of an equal protection argument is the absence of an equal protection clause in the fifth amendment to be applied to the federal government. However, in Bolling v. Sharpe, 347 U.S. 497 (I954), the companion case to Brown v. Board of Education, the Court read an equal protection provision into the due process clause. Although it was specifically stated that the two were not necessarily interchangeable, the Court's later argument that it would not read the Constitution to impose a lesser duty upon the federal government than upon the states should be equally applicable to the type of situation discussed in this article.

${ }^{54} 339$ U.S. 382 (I950).

${ }^{55}$ Labor-Management Relations Act (Taft-Hartley Act) ch. I20, § 9(h), 6I Stat. I46 (I947) (repealed I959).

${ }^{50} 339$ U.S. at 4 I2-I4; see id. at 449-5I (Black, J., dissenting).

${ }^{57} 38 \mathrm{I}$ U.S. 437 (1965), noted in The Supreme Court, 1964 Term, 79 HaRv. L. REv. 56, I20 (I965); cf. United States v. Lovett, 328 U.S. 303 (I946).

${ }_{58}$ Labor-Management Reporting and Disclosure Act of $1959, \$ 504,29$ U.S.C. $\S 504$ (1964). Although $\$ 504$ differs in various ways from the statute upheld in Douds, the Court's reasoning in Brown indicates that the earlier case is effectively overruled. See United States v. Brown, 38I U.S. 437, 457-58 (1965); id. at $464-65$ (White, J., dissenting). 
the narrow class of cases to which it may be applied, renders the right-privilege distinction inconsequential to the extent that the attainder clause protects "privileges," such as access to the NLRB or the privilege of serving as a union officer, as readily as it protects "rights."

Given these several means of limiting or avoiding entirely the effects of Holmes ${ }^{2}$ ruling in McAuliffe, we may well conclude that the right-privilege distinction has lost most of its significance in constitutional litigation. Under these circumstances, we might also conclude that the cutting edge of the right-privilege distinction has been ground down to such an extent that no harm is done by leaving its essential logic unexamined. A respect for the greatness - of Mr. Justice Holmes suggests, moreover, that to tilt at his epigram even after it has ceased to do much mischief is a task likely to degrade the critic far more than to diminish the stature of a great Justice. There is, however, an unfinished feel about these several devices which circumvent the right-privilege distinction, and a humiliating concession common to them all. The implicit concession is that Holmes was correct in his basic position, and that we have managed merely to evade his statement without daring to meet it head on with a convincing intellectual response. This failure to meet Holmes on his own ground means, moreover, that constitutional decision making in the field of governmental relations still follows no predictable course. With this in mind, we turn back one last time to the epigram itself.

\section{AN EPIgram UNDONE}

Mr. Justice Holmes was surely the Supreme Court's master of epigrams, ${ }^{59}$ but he was quick to recognize the spurious seductiveness of the well-turned phrase - even when it was his own. As a general admonition he once remarked: ${ }^{60}$

It is one of the misfortunes of the law that ideas become encysted in phrases and thereafter for a long time cease to provoke further analysis.

Fortunately Holmes did provide a further analysis of his own encysted phrase of $I 892$, that " $[t]$ he petitioner may have a constitutional right to talk politics, but he has no constitutional

\footnotetext{
.59 For a bibliography and collection, see E. BANDER, Justice Holmes, Ex Cathedra (Ig66).

${ }^{60}$ Hyde v. United States, 225 U.S. 347, 39I (rgr2) (Holmes, J., dissenting).
} 
right to be a policeman." The analysis was provided in a brief article in I9I8 in which Holmes developed a concept he had passingly mentioned in The Common Lawe. ${ }^{61}$ Addressing himself to the nature of a legal right, Holmes suggested: ${ }^{62}$

[F] or legal purposes a right is only the hypostasis of a prophecy the imagination of a substance supporting the fact that the public force will be brought to bear upon those who do things said to contravene it - just as we talk of the force of gravitation accounting for the conduct of bodies in space. One phrase adds no more than the other to what we know without it.

Thus Holmes himself readily admitted that to deny that a person had a "right" to something was merely to announce the conclusion that a court would not give him any relief; but the denial itself provides no reason whatever why such relief should be denied. ${ }^{63}$

The impact of the $M c$ Auliffe epigram on succeeding generations of courts has been a dual one. As used by Holmes it represents the inference that because public employment is not protected, retention of that privilege may be conditioned on the giving up of first amendment rights. This non sequitur has been exposed and rejected by the courts applying the unconstitutional conditions doctrine. ${ }^{64}$ The more invidious impact of the epigram, however, has been its use to supply a reason why public status is not protected in the first place - because such status is a

\footnotetext{
${ }^{61}$ O.W. Holmes, JR., The Comamon LAW I6g (M. Howe ed. I963).

62 Holmes, Natural Law, 32 Harv. L. Rev. 40, 42 (IgI8) (emphasis added); see 2 HolMES-Polrock LETTERS 2I2-74 (M. Howe ed. I94I).

Holmes' likening of "right" to "gravity" is doubtless traceable in part to the influence of William James and the very skeptical writings of David Hume, who had used the "gravity" example in precisely the same fashion I7o years earlier. See D. HUMR, AN ENQUIRY CoNCERNing HUMAN UNDERSTANDIng 26-28 (Gateway I956). Unlike Hume, whose skepticism led him to become a confirmed Tory, however, Holmes was led by his own rejection of absolutes generally to embrace the democratic process as the least dangerous means of establishing shortterm political truths.

"3 Holmes was among the first of the legal realists to deflate the use of "right" from a reason in support of a court's decision to a mere tipoff or reiteration of the result. See O.W. Holmes, Jr., The Comaron Law I69 (M. Howe ed. I963). See also Bingham, The Nature of Legal Rights and Duties, I2 MICH. L. REv. I, 7-8, 15-16 (1913); Hohfeld, Some Fundamental Legal Conceptions as Applied in Judicial Reasoning, 23 YALE L.J. I6 (1913).

04 The collateral effect on freedom of speech may not have counted for much to Holmes in I892 simply because constitutional doctrine in that area was not to develop for another 20 years. Holmes himself radically altered his views respecting free speech between 1892 and 1920 . Compare Commonwealth v. Davis, I62 Mass. 510, 39 N.E. II3 (I895), aff'd, I67 U.S. 43 (1897), with Abrams v. United States, 250 U.S. 6I6, 624 (I9I9) (Holmes, J., dissenting).
} 
privilege rather than a right. But, as Holmes' own analysis shows, the epigram on this point plainly yields no reason at all. If we take it as stating a reason, contrary to Holmes' intention, it becomes a perfectly circular argument. This can be seen by substituting Holmes' definition of "right" for the word itself as used in the epigram. Attempting to use the right-privilege distinction as a reason to deny relief to McAuliffe then produces only the following tautology:

Because the public force will not be brought to bear upon those who discharged petitioner, he has no right to be a policeman. And because petitioner therefore has no right to be a policeman, the public force will not be brought to bear upon those who discharged him.

Thus restated, the epigram scarcely presents itself as an adequate basis for extinguishing constitutional review. It plainly does not say why petitioner's dismissal was constitutionally tolerable under the circumstances of the case, nor will continued staring at the epigram ever so enlighten us.

A further examination of Holmes' statement in McAuliffe and of the government's position today, moreover, will indicate that the conclusion in McAuliffe is unsound and undesirable. In rejecting McAuliffe's claim to constitutional protection of his employment status with the government, Holmes appears to declare that an individual's employment interest in the public sector stands on no higher constitutional footing than individual employment interests in the private sector. ${ }^{65}$ The point emerges for a second time in Commonvealth v. Davis: ${ }^{\text {B8 }}$

For the Legislature absolutely or conditionally to forbid public speaking in a highway or public park is no more an infringement of the rights of a member of the public than for the owner of a private house to forbid it in his house.

If Holmes' reasoning was that infringements in the public sector which are no greater than nor different from infringements in the private sector can be no more subject to constitutional restraint than are the private infringements, his point, no matter how plausible it seems when read quickly, is a non sequitur. To be sure, the fourteenth amendment leaves private infringements unaffected, and it does so whether such infringements are great or small, reasonable or arbitrary. That, after all, was the lesson of

\footnotetext{
${ }^{65}$ See p. 1439 supra.

${ }^{68}{ }_{\text {I62 }}$ Mass. 5IO, 5II, 39 N.E. II3, II3 (I895), aff'd, I67 U.S. 43 (I897).
} 
the Civil Rights Cases ${ }^{67}$ in their literal rendering of the amendment: that it is only a "state" which is forbidden to ignore due process and equal protection in its dealings with individuals. Far from providing that states are under no greater obligation to observe due process in the conduct of their enterprises than are private employers or home owners in the management of similar enterprises, however, the amendment expressly distinguishes the two situations for constitutional purposes and provides that it is specifically the state (if only the state) which must observe due process. And the amendment does not say that "no State, except when acting in a proprietary capacity," shall deny due process; rather, it makes no distinction at all respecting the capacity in which the state acts.

Even if the text of the fourteenth amendment were less clear and even if there were room for a distinction to be made between "proprietary" and "governmental" state action there would be no reason to make it. As a wholly original proposition, it is difficult to see any need to vouchsafe to government the prerogative of arbitrary power or of fundamental unfairness in its conduct of a public undertaking. A minimum demand of uniformly reasonable rules in the management of public largess is surely an unexceptionable requirement of constitutional government. Indeed, the fact that arbitrary decision making in the private sector is not subject to constitutional restraint makes it even more important to provide individuals with an alternative sphere of activity by foreclosing such power in the public sector. ${ }^{68}$

With the increasing size of government as an economic unit, moreover, it is simply no longer true that a particular infringement related to employment by government is no greater than a particular infringement made by a private employer. Holmes' conclusion that there is "no constitutional right to be a policeman" may have been influenced by the comparatively small economic role played by governmental units in I892. Excluding McAuliffe from public employment still left open to him a very large percentage of the available employment in the country. But today the federal and state governments directly or indirectly control a great proportion of the nation's employment; if one is unable

\footnotetext{
${ }^{67}$ rog U.S. 3 (1883).

${ }^{68}$ This is not to imply that government may not act in the interests of efficiency, economy, or a "maximizing of profits"; quite the contrary. But if the government is to act in a fashion detrimental to any citizen, whether government employee, government contractor, or welfare recipient, it should have a rational purpose for its action which relates to the function which it is performing.
} 
to hold public employment, his chances of personal economic success are significantly limited. Not only is he excluded from a substantial portion of the available jobs, ranging from postman to nuclear scientist, but his bargaining power with other employers is proportionately decreased. And the expansion of government with its attendant influence on the individual is not limited to employment, for the government is playing an increasingly crucial role in other areas such as housing, education, and welfare. In the field of welfare especially, the individual's alternatives to acceptance of arbitrary government action are practically nonexistent, and the potential control over his personal life is therefore practically absolute. This substantial influence which expanded governmental activity gives the government over the private lives of its citizenry makes the restraints of substantive due process necessary. Indeed, a failure to demand substantive due process of government even as it expands would be a constitutional incongruity against the emerging trend to bring private decision makers within the Constitution when the impact of their enterprises becomes so great that the power they wield is functionally equivalent to that traditionally exercised only by government. ${ }^{68}$

If, under a functional analysis, the conclusion reached by Justice Holmes in 1892 is no longer viable, then Holmes' own methodology should be used to label an individual's interest in his public status a "right" directly protected against unreasonable regulation. Such unreasonableness need involve only the lack of a sufficient connection with an adequately compelling public interest to warrant subordinating the individual interest under the circumstances. The protection of an employee's job interest, a student's interest in public education, or a tenant's interest in public housing would thus not depend upon the fortuitous involvement of still other protected rights. These other rights might enhance the individual's claim and they might make it even clearer that the regulation in question is constitutionally unreasonable, but they would not be indispensable to the petitioner's success.

The application of the view that substantive due process applies directly to status interests in the public sector, has been confirmed

${ }^{69}$ See Marsh v. Alabama, 326 U.S. 5or (I946); cf. Evans v. Newton, 382 U.S. 296 (Ig66) ; Terry v. Adams, 345 U.S. 46r, 48I-84 (I953) (separate opinion of Clark, J.). See generally Berle, Legal Problems of Economic Power, 60 CoLuMr. L. REV. 4, 4-6, 9-IO (Ig60). 
in some recent judicial action. In I96I, for example, the Fifth Circuit laid aside the right-privilege tradition in protecting the interest of a student in completing his college education at a public university. ${ }^{70}$ Its decision was followed in a case involving school suspensions, in which a district court commented: ${ }^{71}$

Whether the interest involved be described as a right or a privilege, the fact remains that it is an interest of almost incalculable value, especially to those students who have already enrolled in the institution and begun the pursuit of their college training. Private interests are to be evaluated under the due process clause of the Fourteenth Amendment, not in terms of labels or fictions, but in terms of their true significance and worth.

And the Supreme Court appeared to agree when it ordered New York to reinstate a professor at Brooklyn College who had been discharged because of his refusal to testify before the Senate Internal Security Subcommittee. ${ }^{72}$

We may be a long time in working out the content of substantive due process in the public sector, just as we have been a long time evolving its standards in the private sector. Overzealous courts may err too far in the protection of this "new property," and then shift violently to the other extreme, just as they once overextended themselves in behalf of the old property, only ultimately to leave it to the mercies of the political process. ${ }^{73}$ But that under appropriate circumstances one's interest in his government job, his publicly financed home, his food stamp meals, or his state university educational opportunities may indeed be

\footnotetext{
${ }^{70}$ Dixon v. Alabama State Bd. of Educ., 294 F.2d I50 (5th Cir.), cert. denied, 368 U.S. 930 (Ig6r).

${ }^{71}$ Knight v. State Bd. of Educ., 200 F. Supp. I74, I78 (M.D. Tenn. I96I).

${ }^{72}$ Slochower v. Board of Higher Educ., 350 U.S. 55I, 555 (1956):

To state that a person does not have a constitutional right to government employment is only to say that he must comply with reasonable, lawful, and nondiscriminatory terms laid down by the proper authorities.

Cf. Flemming v. Nestor, 363 U.S. 603 (Ig60) (social security benefits). See also Bagley v. Washington Twp. Hosp. Dist., 65 Cal. 2d 499, 42I P.2d 409, 55 Cal. Rptr. 40 I (Ig66); Finot v. Pasadena City Bd. of Educ., 58 Cal. Rptr. 520 (Dist. Ct. App. 1967$)$.

${ }^{73}$ See, e.g., Lochner v. New York, I98 U.S. 45 (I905). See also Hetherington, State Economic Regulation and Substantive Due Process of Law, 53 Nw. U.L. Rev. I3 (1958); McCloskey, Economic Due Process and the Supreme Court: An Exhumation and Reburial, I962 Sup. Cr. Rev. 34; Reich, The New Property, 73 YaLE L.J. 733 (1964). The phrase, "new property," belongs to Professor Reich. It is already too well established to be displaced, but I mildly regret its use; it may imply that the Court should be only as diligent in protecting status in the public sector as in protecting the old property from state regulationwhich would result, of course, in scarcely any protection at all.
} 
[Vol. 81:1439

constitutional rights in the positive-law sense ought no longer be denied. That these interests may be regulated compatibly with other competing interests need not be denied either, any more than it can be denied that interests in private property may be regulated by zoning ordinances, sanitation codes, building permits, or antidiscrimination laws. Any per se constitutional distinction which would exclude governmental regulation of status in the public sector from constitutional review would, to steal a phrase from Mr. Justice Holmes, reflect neither logic nor experience in the law. 